\title{
Павел Басинский
}

https://doi.org/10.18485/ai_knjiz_u_prevodu.2019.ch6 821.161.1.09-31 Водолазкин, Е. Г.

\section{БУДУЩЕГО НЕТ О ПРОЗЕ ЕВГЕНИЯ ВОДОЛАЗКИНА}

Выступая в парижской Олимпии, не могу сыграть тремоло. Точнее, играю, но нечетко, нечисто - так, как это делают начинающие гитаристы, издающие глухое бульканье вместо нот. Никто ничего не замечает, и Олимпия взрывается овациями. Я и сам забываю о своей неудаче, но, садясь под крики поклонников в лимузин, ловлю себя на характерном движении пальцев. Правая рука, словно искупая допущенную ошибку, исполняет теперь уже не нужное тремоло.

Пальцы двигаются с невероятной скоростью. Касаются воображаемых струн. Так ножницы парикмахера, оторвавшись на мгновение от волос, продолжают стричь воздух. Подъезжая к аэропорту имени Шарля де Голля, выстукиваю неудачно сыгранную мелодию на стекле ничего сложного. Как я мог запнуться на концерте?

\section{«Брисбен»}

Говорил ей: в холода носи шапку, иначе отморозишь уши. Посмотри, говорил, сколько сейчас прохожих без ушей. Она соглашалась, мол, да-да, надо бь, но не носила. Смеялась над шуткой и продолжала ходить без шапки. Такая вот картинка вспльла в памяти, хотя о ком здесь идет речь - ума не приложу.

Или, допустим, вспомнился скандал - безобразный, изнурительныци. Непонятно где разыгравшийся. Обидно то, что начиналось общение хорошо, можно сказать, доброжелательно, а потом слово за слово все пе- 
реругались. Главное, самим же потом стало удивительно - почему, зачем?

Кто-то заметил, что часто так бъввает на поминках: часа полтора говорят о том, каким покойник был хорошим человеком. А потом кто-то из пришедших вспоминает, что был покойник, оказывается, не только хорошим. И тут, как по команде, многие начинают высказываться, дополнять - и мало-помалу приходят к выводу, что был он, вообще-то, первостатейным мерзавцем.

Или совсем уж фантасмагория: кому-то дают по голове куском колбасы, и вот этот человек катится по наклонной плоскости, катится и не может остановиться, и от этого качения кружится голова...

Моя голова. Кружится. Лежу на кровати.

«Авиатор»

В разное время у него было четыре имени. В этом можно усматривать преимущество, поскольку жизнь человека неоднородна. Порой случается, что ее части имеют между собой мало общего. Настолько мало, что может показаться, будто прожиты они разными людьми. В таких случаях нельзя не испытывать удивления, что все эти люди носят одно имя.

«Лавр»

Три цитаты из начал трех романов Евгения Водолазкина: «Брисбен», «Авиатор» и «Лавр». Я привожу их в порядке, обратном их написанию, сознательно, потому что время у автора часто движется не вперед, а вспять, что, например, в «Авиаторе» является главным приемом.

Точнее сказать, время у Водолазкина движется по кругу, а еще точнее - по спирали, где конец верхнего 
витка оказывается строго над началом первого. В том же «Авиаторе» разговор в самолете:

- Ymo bul всё nuueme?

- Описьваю предметь, очушения. Людей. Я теперь каждьй день пишу, надеясь спасти их от забвения.

- Мир Божий слишком велик, чтобь рассчитьвать здесь на ycnex.

- Знаете, если каждьй опишет свою, пусть небольшую, частииу этого мира... Хотя почему, собственно, небольшую? Всегда ведь найдется тот, чей обзор достаточно иирок.

- Например?

- Например, авиатор...

- который перед началом романа дается в качестве эпиграфа, приводится в самом его конце, как завершающая роман точка. Но теперь мы уже другими глазами читаем этот разговор; к тому же автор провоцирует нас вернуться в начало романа и прочитать его снова, и опять же - другими глазами.

Что объединяет три цитаты, которые привел? Кроме тональности, которая у Водолазкина всегда строго выверена?

Чувство незавершенности. Отсутствия целого.

Главный герой «Брисбена» гитарист Глеб Яновский, кажется, достиг предела совершенства в игре, но в этот момент его и поражает болезнь Паркинсона, которая для гитариста является приговором. Став мастером, он не может исполнить простейшее тремоло.

В «Авиаторе» герой, Иннокентий Платонов, оказался в будущем, в котором его по законам биологии быть не должно, во всяком случае - не должно быть в молодом возрасте. Его заморозили во время эксперимента в Соловецком лагере, и вот он оказался в нашем 
времени, в котором исторически не был запланирован. Нарушена не только цельность, последовательность жизни героя, но и цельность, последовательность исторического времени, где каждому поколению отведена своя ниша, свой отрезок времени. К тому же заморозка стала причиной амнезии главного героя, и весь роман он обречен мучительно, но и радостно - как избавляются от любой тяжкой болезни - вспоминать свое прошлое, нащупывая в своей памяти самый важный, узловой момент, который он опять же вспомнит только в самом конце романа, заставив читателей в свою очередь вспоминать: а что же тогда произошло на самом деле, в начале XX века, и кто на самом деле этот герой - жертва или палач? На протяжении всего романа он сам себе представлялся жертвой обстоятельств, так и читатели его воспринимали, но последняя вспышка его памяти вдруг обнаруживает, что Иннокентий вообще-то сам убийца и, значит, пострадал-то он вовсе не напрасно.

В романе «Лавр» у героя не то что нет цельной личности, у него нет одного имени, а имя для средневекового человека много значило, без имени он был совершенно неразличим. У героя четыре имени и два прозвища.

Во всех трех романах Водолазкин обманывает ожидания читателей. Задача романного героя - преодоление Судьбы или гибель под ее ударами как отражение прометеевой трагедии борьбы с богами. По этой логике знаменитый гитарист, заболевший Паркинсоном, должен доказать, что и в этом состоянии он на что-то способен и даже может подняться на ступеньку выше в своем искусстве. Собственно, весь роман к этому и ведет: появляется девочка Вера, обладающая исключительными музыкальными способностями, и она с героем составляет дуэт, который потрясает публику боль- 
ше, чем выступления Яновского соло. Но Вера умирает, и герой оказывается у того же разбитого корыта, как пушкинская старуха. Кстати, смерть Веры - тоже противозаконна по романным критериям - для чего тогда вообще весь этот сыр-бор со случайно появившейся в жизни героя дочерью его первой возлюбленной (но его дочерью) затевался, не для того же, чтобы всего лишь напомнить, что человек предполагает, а Бог располагает? Да, это так, ну и что? Романы не для напоминания этой истины пишутся. Или это не роман, или роман о чем-то другом. Роман о том, что Глеб, может быть, и оказался у разбитого корыта, но это уже совсем другой Глеб, и будет ли он играть на гитаре, не будет ли, уже не суть важно. Другой человек, другая жизнь, с чистого листа, но с памятью о том, что было на этом листе раньше.

Ты полагаешь, что время здесь не круг, а какая-то разомкнутая фигура, спросил у стариа Амвросий (он же Савелий, он же Устин, он же Лавр - П. Б.).

вот именно, ответил стареи. Возлюбив геометрию, движение времени уподоблю спирали. Это повторение, но на каком-то новом, более высоком уровне. Или, если хочешь, переживание нового, но не с чистого листа. С памятью о пережитом прежде.

«Лавр»

В романе «Лавр» герой тоже живет по спирали, проходя свои четыре круга, по названиям четырех частей, и трижды меняет свое имя, а с ним и свою личность. И в результате оказывается вроде бы у того же разбитого корыта: он должен принимать роды у женщины, и это будет незаконнорожденный ребенок. Первый родился мертвым, второй - живым, но умирает сам Лавр. Чет- 
вертый виток спирали останавливается над началом первого.

Перед тем как писать этот текст, я перечитал все три романа Водолазкина и обнаружил в них одну едва ли случайную закономерность. Все дети главных героев - не их биологические дети.

В «Брисбене» Вера, по законам классического романа, должна быть внебрачной дочерью Глеба. Это давало бы развитию действия новый толчок. Внебрачный, случайно обнаружившийся ребенок, в литературе ли, в кинематографе ли, это всегда как бы продолжение героя в будущем, как бы старт для преодоления логики Судьбы, которая подчинила себе жизнь героя. Но Вера не его дочь. Это было бы слишком по законам романной интриги. Вера - просто дочь, просто ребенок, и вот за него Глеб должен отвечать.

Настя в романе «Авиатор» могла бы быть внучкой главного героя; ее бабушка была его возлюбленной, но она не его внучка, так что мексиканского сериала опять не получается.

И наконец, благополучно рожденный в конце романа «Лавр» мальчик - тоже не сын героя, хотя, по сути, он дарит ему жизнь вместе с его матерью. Дарит жизнь, и сам умирает с ребенком на руках.

Возможно, я что-то преувеличиваю, и у автора не было такого замысла: обрывать биологическую жизнь героя, его продолжение в детях. Тем более что в «Авиаторе» эта линия как бы намечена: вторая Настя становится возлюбленной Платонова и должна родить от него девочку. Но это как раз не самая сильная интрига в романе, в ней есть что-то искусственное, она отдает каким-то дурным повторением: Настя-первая, Настя-вторая... Отношения между Верой и Глебом в «Брисбене» куда более трогательные и пронзительные. 
Она для него становится настоящим подарком судьбы, даже в какой-то степени смыслом его нового существования, и именно потому, что это просто чудесный ребенок, а не его биологическая дочь.

Но вернемся к категории времени в романах Водолазкина.

Иногда кажется, что автор не просто смеется над временем, он издевается над ним. Один из его фирменных приемов - это внезапная смена повествования в прошедшем времени на настоящее. В «Лавре» этот сбой в повествовании поначалу представляется даже редакторским упущением, но потом к нему привыкаешь. Этот сбой рождает особый драйв, позволяет повествованию как бы продышаться, очистить кровь, чтобы она бежала по жилам с новой скоростью. Смена времени повествования - это всегда смена темпа. В настоящем времени все читается энергичнее, быстрее, как если бы во время чтения классического романа вы переключились на газетный лист с репортажем. В средневековом контексте «Лавра» это рождает особое впечатление, сродни «американским горкам».

В «Авиаторе» временные сбои становятся пульсирующими, в пределах одного абзаца, иногда одной фразы:

Я выташил из-под одеяла правую руку и почувствовал бережное рукопожатие Гейгера... Я не мог этого подтвердить. Если он так говорит, значит, имеет на то основания... Я молча спрятал руку под одеяло... Я покачал головой... Выдержав паузу, говорю скрипуче... Я почувствовал, как меня душат слезы... Спокойно смотрит на меня...

Это не из разных фрагментов текста, это один фрагмент, все это происходит (происходило) в одно время в одной больничной палате.

В «Брисбене» автор разваливает повествование пополам: Глеб ведет дневник или записки в настоящем 
времени, а история его детства, отрочества и юности рассказывается в прошедшем, к тому же повествование в дневнике-записках ведется от первого лица, а флэшбеки или, по-старинному, ретроспекции - в третьем лице, что рождает иллюзию одновременного проживания двух героев: «я» и Глеба.

Кстати, это постоянная, ритмичная смена нарратива для читательского зрения является довольно болезненной, как если бы переводить взгляд с дальнего предмета на ближний или с обзора из окна на какую-то деталь на подоконнике - есть такая зарядка для глаз, но она не может быть слишком продолжительной, глазная мышца быстро устает. Но чтение романов Водолазкина - это вообще труд, вопрос лишь в том, насколько он оправдан для того или иного читателя. Мне кажется, что странный, явно непредсказуемый успех романов Водолазкина отчасти объясняется еще и этим парадоксальным фактом: читатели сегодня устали от слишком легкого восприятия текстов в соцсетях и охотно готовы потрудиться, потренировать читательское зрение на куда более сложных текстах Водолазкина. Тем более что как автор он проявляет исключительную вежливость к своему читателю, и вообще в самой тональности его прозы есть какое-то исключительное человеческое обаяние, как и в его тонком или, как сказала одна моя умная знакомая, «вкрадчивом» чувстве юмора.

Но опять вернемся к категории времени.

«Лавр» имеет авторское жанровое определение «неисторический роман». Едва ли дело здесь только в том, что автор принципиально не желал писать роман о Средневековье как оно было, тем более что никто точно не знает, каким оно было на самом деле, особенно русское Средневековье, где даже литературы как таковой еще не было. Но «Лавр» вообще не о Средних 
веках. Но и не о современности. Вот это было бы настоящей ошибкой писателя, если бы на средневековом материале он заговорил о современности. Таких подмен, особенно - в кинематографе, пруд пруди, и читать (смотреть) это все невыносимо. «Лавр» о другом.

Это роман о личности, которая существует вне Истории. Это безусловно средневековое мировосприятие, но оно, именно в силу романности героя, переживается тут как индивидуальное, в этом восхитительный парадокс романа.

Водолазкина опрометчиво окрестили «русским Умберто Эко», но это, конечно, глупое сравнение. Я бы скорее назвал его русским Сервантесом, если бы это не звучало так пафосно и пошло. Между его Лавром и испанским идальго куда больше общего.

В Средневековье личность сама по себе ничего не значила и всякого рода «экзистенциалистские» переживания там были неуместны, это уже забавы девятнадцатого, а еще более двадцатого века. Но жизнь Лавра - это, конечно, непрерывное «экзистенциалистское» переживание, поэтому он и вызывает сочувствие у современного читателя. В этом главный парадокс романа, и я даже не знаю, какой в этом можно найти большой смысл, но как душевный тренинг этот роман поразительное явление. А смысл? А какой вообще у искусства смысл?

В «Авиаторе» автор вроде бы обращается к Истории: революция, Соловки, 90-е годы XX века с их уже историческими приметами... И вроде бы смысл этой вещи в том, что с обретением исторической памяти, избавлением от амнезии главный герой должен обрести цельность своей личности. Так сказать, замкнуть цепь времен. Но как же можно замкнуть эту цепь, если как минимум полвека герой находился в анабиозе, то 
есть страна жила, мир жил, а он, по сути, нет? Ну да, он вернулся в прошлое, нащупал там самые главные узловые точки, вернул себе память, но памяти о жизни целого поколения у него нет и быть не может. Поэтому и его любовный роман с Настей - это какой-то нонсенс, это даже не любовь «деда» с «внучкой», это любовь инопланетянина с современной землянкой.

И вот что важно: как раз с окончательным обретением памяти жизнь героя буквально повисает в воздухе. У самолета, на котором он возвращается из Мюнхена в Россию (Мюнхен присутствует в двух романах Водолазкина не просто как зарубежный европейский город, но как устойчивый топос «не России»), не выпускаются шасси, и будущее героя представляется зыбким. Впрочем, оно представляется зыбким и без этого; он сам является таким самолетом без шасси.

В «Брисбене» мать главного героя живет мечтой о будущем, о прекрасном австралийском городе Брисбене, где она однажды поселится, и тогда-то и начнется настоящая жизнь, а до этого - сплошной черновик, репетиция жизни... Но вместо Брисбена оказывается в могиле. Мне кажется, это единственный момент в прозе Водолазкина, где он позволяет себе черный сарказм.

Но и главный герой, Глеб Яновский, который безусловно является как бы продуктом советской Истории, конкретно советской украинской или киевской истории, на самом деле начинает свое истинное существование, когда теряет решительно все - не только способность играть на гитаре, но и приемную дочь Веру, его единственную надежду на продолжение музыкальной карьеры. Что будет с Глебом дальше - не понятно. Это уже другой человек.

Я не берусь сейчас в рамках небольшого текста делать выводы: почему в прозе Водолазкина это так. 
Почему у его героев нет определенного будущего, хоть сколько-нибудь представляемого. Но, может быть, самое сильное впечатление, которое остается от его прозы, я бы передал двумя словами: БУДУЩЕГО НЕТ. А, следовательно, и ИСТОРИИ НЕТ, потому что нет никакого смысла в Истории, если мы не можем хоть както предвидеть будущее. Тогда зачем она?

Но странно: это впечатление (повторяю, лично для меня очень сильное) не рождает чувства безнадежности. Строго говоря, ведь будущего действительно нет, потому что мы живем в нем ежесекундно, как и в настоящем. Мы этого не замечаем, но это так.

Жизнь - сама по себе величайшая ценность...

В романе «Брисбен» маленький Глеб рассматривает тело утонувшей девушки. До этого, по дороге на пляж, он видел ее со спины.

Девушка. Видимая со спины: с рассыпавшимися по плечам русыми волосами, в красно-черном купальнике, с завязанным на поясе длинным просвечивающим платком. На правой руке - плетеный браслет из голубой проволоки. Глеб с Антониной Павловной шли босиком, держа в руках сандалии. Девушка тоже шла босиком. Несла на плече соломенную пляжную сумку - может быть, сандалии тежали там. Шагала широко, как-то даже по-балетному, а Глеб копировал ее походку и старался попадать своими ступнями в ее следь.

И вот она уже мертвое тело:

Глеб рассматривал его и находил прекрасным. Прямой нос. Тонкие полураскрытые губы. Только в изменившемся ивете губ была смерть, да еще в остановившемся взгляде. Больше ни в чем. Но глаза совершенно определенно говорили, что жизнь кончилась. Почему никто их не закрыл? Глеб никогда не видел это лиио живым, потому что шел позади девушки. Всего-то нужно 
было - забежать вперед и посмотреть. Она бы выразила удивление. Засмеялась бы, махнула рукой. Может быть, даже фыркнула - мало ли на что способен человек, когда к нему проявляют внимание. Сейчас удивлять ее бесполезно...

Вот вам в миниатюре и вся История - с ее прошлым, которое было, и будущим, которого нет. И жизнью, которая есть, но мы ее почему-то не оценили. Не ценим.

Это один из смыслов прозы Водолазкина. Я не уверен, что самый главный. Но важный...

Pavel Basinsky

\section{NO FUTURE: ABOUT PROSE OF EUGENE VODOLAZKIN}

While performing at Paris Olympia, I cannot play a tremolo. More precisely, I play, but indistinctly, uncleanly - just like beginner guitarists do, emitting a dull gurgle instead of clear notes. No one notices anything, and Olympia explodes with a standing ovation. I myself have forgotten my failure, but, sitting down in a limousine followed by the cries of fans, I catch myself on the characteristic movement of the fingers. The right hand, as if redeeming the mistake made, now performs the now unnecessary tremolo.

Fingers move with incredible speed, touching imaginary strings. So do the barber's scissors, breaking away from the hair for a moment, continue to cut air. As I approach the Charles de Gaulle Airport, I tap out an unsuccessfully played melody on glass - nothing complicated. How could I have stumbled at a concert? 